\title{
Predicting Accuracy of Valuation Multiples Using Value Drivers: Evidence from Indian Listed Firms
}

\author{
Vandana Gupta \\ FORE School of Management, New Delhi, India \\ Email: vandana@fsm.ac.in
}

How to cite this paper: Gupta, V. (2018) Predicting Accuracy of Valuation Multiples Using Value Drivers: Evidence from Indian Listed Firms. Theoretical Economics Letters, 8, 755-772.

https://doi.org/10.4236/tel.2018.85052

Received: January 31, 2018

Accepted: March 16, 2018

Published: March 19, 2018

Copyright $\odot 2018$ by author and Scientific Research Publishing Inc. This work is licensed under the Creative Commons Attribution International License (CC BY 4.0).

http://creativecommons.org/licenses/by/4.0/

\section{(c) (i) Open Access}

\begin{abstract}
The objective of this research study is twofold: 1) to evaluate the prediction accuracy of four valuation multiples across three sectors for Indian listed firms and 2) to identify the fundamental drivers for these multiples. The valuation multiples identified for this study are: price to earnings $(\mathrm{P} / \mathrm{E})$, price to book value $(\mathrm{P} / \mathrm{BV})$, price to sales $(\mathrm{P} / \mathrm{S})$ and enterprise value to earnings before interest, depreciation, tax and amortization (EV/EBIDTA) and the sectors taken are steel, banking and automobile. Multiple regression methodology is followed with the valuation multiple as dependent variable and the value drivers as independent variables, to get predicted multiples on 470 firm observations. By regressing the multiples on fundamental variables, the best suited multiple for each sector and the key drivers of the multiple are obtained. The empirical findings based on root mean square error (RMSE) and Theil coefficient reveal that least prediction errors are observed in P/S and EV/EBIDTA for the automobile sector, EV/EBIDTA for the steel sector and $\mathrm{P} / \mathrm{BV}$ for the banking sector. It is also observed that the significant variables that explain these multiples are beta, return on equity (ROE), return on capital employed (ROC), dividend payout ratio (D/P) and net profit margins (NPM). These findings are in line with the derivation of fundamental drivers for each multiple as explained in Gordon model. Damodaran: 2007 [1]. The present work contributes to emerging market literature on equity valuations and attempts to compare valuations based on market approach using value drivers. A comparison of forecasts with actuals helps in recommendations to buy/sell/accumulate/hold for equity investors and is also pertinent for market participants and financial regulators.
\end{abstract}

\section{Keywords}

Equity, Valuations, Prediction, Earnings, Book Value, Enterprise Value 


\section{Introduction}

\subsection{Concept of Valuation}

Valuation is the estimation of an asset's value based on variables perceived to be related to future investment returns; on comparisons with similar assets; or on estimates of immediate liquidation proceeds. Valuation analysis is performed on a number of corporate events such as public issue, merger, de-merger, and ESOP issuance. Analysts also value listed securities frequently to give their views on them (Buy/Sell/Hold/Accumulate).

\subsection{Valuation Models}

Broadly valuation models can be classified into two types as given below.

- Absolute valuation models: Absolute valuation models specify an asset's intrinsic (fundamental) value. The most fundamental technique applied is the discounting of future cash flows (DCF technique). DCF analysis involves estimating the cash flows associated with the company and then discounting these cash flows by a discount rate commensurate with their risk level. However, estimating future cash flows involves multiple assumptions and hence becomes highly subjective. Moreover, accurately estimating the company's cash flows and choosing the appropriate discount rate is difficult, thus, DCF analysis is often abandoned in favor of valuation by multiples.

- Relative valuation models or Valuation by Multiples: Relative valuation models specify an asset's value based on how similar assets are currently priced by the market.

Proponents of the DCF method attempt to estimate the intrinsic value of an asset by focusing on the asset's fundamentals Damodaran, 2007:5 [1]. The results of a survey conducted by PricewaterhouseCoopers PwC 2008:13 [2] revealed that the discounted cash flow technique is used more frequently than market-based technique such as the price earnings (P/E) ratio. Opponents to the DCF approach however, point out that the focus of DCF models is on the discounting of forecasted future cash flows, the estimation of which can be unreliable. The DCF approach can also be rather cumbersome and rests on a range of sensitive assumptions Lie and Lie [3]. Thus, alternatively valuation multiples are used.

Some of the merits of using valuation multiples are:

- Multiples are easy to understand and simple to present to clients and customers.

- Financial newspapers, magazines, and online platforms publish common trading multiples daily, and regularly update them.

- Sell-side analysts frequently communicate their beliefs about the value of firms in terms of multiples within their research reports.

- Screening on multiples-fundamental screening-allows quick comparisons between firms, industries, and markets.

- Multiples reflect the current mood of the market, since their attempt is to measure relative and not intrinsic value 


\subsection{Price Valuations}

When studying price valuations by applying multiples, there are usually two assumptions on which these forecasts rest: 1) value is proportional to the fundamental used (for example, earnings, revenue, cash flow, book value), and 2) a similar proportionality holds for "comparable" companies, that is, firms from the same industry or with similar characteristics (for example, size, leverage, expected growth). It is widely believed and established that the multiple being applied varies across industries.

The stock price is estimated based on a specific value driver and the benchmark multiple. This benchmark may be the industry multiple or median. For the purpose of benchmark valuation, the companies identified are based on several criteria namely, the industry, growth rate, risk characteristics and size. Alford 1992 [4] identified several parameters for comparable firms which included size (surrogate for risk), ROE (surrogate for growth) and industry type.

The multiples are largely classified based on earnings, book value, revenue and EBIDTA. By and large, variants and extensions of these multiples are applied, based on the specific purpose for which valuation is being done, nature of industry and other characteristics.

The multiples which are more commonly applicable are:

- Price to book value (P/BV): This multiple is used commonly for valuation of banks and financial services (insurance sector). Some of the other industries where this multiple is applied are paper and real estate. Bernard 1994 [5] stated that variations in P/BV can be explained to a large degree by ROE. This ratio is related to profitability, as also risk and growth. Chan and Chen 1991 [6] advocate that this multiple reflects the production efficiency of a firm.

- Price to sales (P/Sales): This multiple is commonly used for valuation of retail sector, and fast moving consumer goods sector.

- Enterprise value to EBIDTA (EV/EBIDTA): Here, enterprise value refers to the market value of equity and debt and EBIDTA is the operating profit before interest, depreciation, tax and amortization. This is a significant tool used by analysts for valuation of firms. Often, this tool is applied in combination with the DCF (discounted cash flow) technique to arrive at a fair value of the firm. This is used more in the context of valuation of firms rather than valuation of equity. One limitation of this method is that unlike the DCF technique, it does not include changes in working capital and capital investments for its computation.

- Price to earnings (P/E): Among all the relative valuation tools, price to earnings is the one used most commonly and also across all sectors. One of the merits of this method of valuation is that it captures both the risk and growth of stock, thus it is a close reflection of the true value. However, one of the main limitations of this tool is that for those companies with negative earnings, this tool cannot be applied. Thus firms with net losses or where 
there is a wide difference between basic and diluted earnings per share, applying this multiple may not give the best results.

It is important to examine the valuation accuracy for emerging markets as unlike developed markets the taxation structure, reporting standards, liquidity and other factors differ widely and may thus warrant identifying different multiples as compared to studies in developed countries. Moreover, with increasing investment by foreign institutional investors, it is imperative to have valuation accuracy in prediction to ensure influx of funds and sustained investors' interests.

\subsection{Objectives of the Study}

It is against this background that the present study chooses to evaluate the prediction accuracy of alternative multiples for companies across three sectors: Banking, Steel and Automobile for the years 2014-16. More specifically the objectives are:

1) To regress the multiple with its key drivers as explanatory variables and obtain the predicted multiple.

2) To identify the significant key drivers for the multiple.

3) To analyze the predicted multiple for its accuracy in giving least prediction error and

4) To thus suggest the best fit multiple for each sector.

The paper is organized as follows. Section 1 is on Introduction while Section 2 reviews related literature. Section 3 describes the research design and methodology while Section 4 gives the empirical findings. Section 5 concludes and includes limitations of the existing study and scope for future research.

\section{Review of Literature}

Bulk of prior research is focused on either how comparable firms are identified for the simple multiple valuation, or which valuation multiple is superior in terms of its valuation accuracy.

Among the studies wherein regression technique is applied for developing forecasted multiples, Kisor and Whitbeck 1963 [7] developed a regression model of $\mathrm{P} / \mathrm{E}$ ratios with independent variables of growth rate in earnings, dividend payout ratio and standard deviation of EPS changes. A similar analysis by Cragg and Malkiel 1968 [8] established growth rate, payout ratio and beta for stocks as independent variables. Zarowin 1990 [9] studied the relationship between P/E ratios and analyst forecasts of growth and concluded that long-term growth has a positive impact on P/E ratios. Chen and Chan 1991 [6] advocated that price to book value reflects the production efficiency of a firm.

Among the studies on comparable companies' approach, one by Agnes and Ray 2000 [10] evaluated the valuation accuracy of PE, PBV and combined PE\& PBV multiples. Their findings revealed that PE benchmark valuation method performs better than PBV while combined multiple outperforms the other two. They concluded that though earnings are better indicators of a firm than book 
value, neither can be substituted for the other. Kaplan and Ruback 1995 [11] estimated valuations for a sample of highly leveraged transactions (HLTs) based on market value to EBITDA. The benchmark multiples were the median multiples for companies in the same industry, companies that were in similar transactions, or companies in the same industry that were involved in similar transactions. While their findings were that DCF valuations approximate transaction values reasonably well, they also found that simple enterprise value to earnings before interest, taxes, depreciation, and amortization (EV/EBITDA) multiples results in similar valuation accuracy.

Similarly, Kim and Ritter 1999 [12] used several measures for the matching companies in the valuation of IPO companies. The multiples used in their study were $\mathrm{P} / \mathrm{E}, \mathrm{P} / \mathrm{BV}, \mathrm{P} /$ Sales, EV/sales, and EV/EBITDA. They found that all these multiples yield positively biased estimates but that EBITDA multiple results in the most precise valuation, particularly for the more established IPO companies. They also showed that valuations improve when forecasted earnings rather than historical earnings are used and advocated that comparable companies should be identified by a specialist research firm rather than an algorithm.

Hotchkiss and Mooradian 1998 [13] used relative valuation multiples to estimate the value of bankrupt companies. They compared these values with the acquisition prices to determine the degree of discounting associated with bankrupt companies. The multiples they applied were the ratios of EV/sales and of EV/assets. They reported that bankrupt companies are acquired at discounts of 40 - 70 percent. Pablo Fernandez 2002 [14] in his study on equity valuations found that while multiples have broad dispersion, a comparison with multiples of comparable firms helps in evaluating the reasons for differences between valuations across different firms. Yoo 2006 [15] examined a comprehensive approach to combine several simple multiple valuation outcomes to improve the valuation accuracy of the simple multiple valuation techniques.

Lie and Lie 2002 [3] evaluated multiples used by practitioners for estimating a company's value. They opined that $\mathrm{P} / \mathrm{BV}$ gives the best estimate of firm value as compared to all other multiples. They also concluded that forecasted earnings are better indicators of firm value as compared to trailing earnings; EBIDTA as compared to EBIT but ultimately the performance of multiples varies with size, profitability and several other characteristics of a firm. Nel 2009, 2010 [16] [17] critically examined the gap between what academicians propose and what is practiced by investment bankers and financial advisors with respect to equity valuations. The results revealed that, although academia and investment practitioners both favor the PE ratio and agree on the suitability of earnings and sales as value drivers; they disagree significantly with regard to other multiples and value drivers. Nissim 2013 [18] compared alternative valuation methods and emphasized the relevance of book value multiples over earnings multiples in valuation of insurance companies. They also stated that when book value multiples are conditioned to ROE, it improves the accuracy significantly. 
Popular belief suggests that different sectors have different "best" multiples: Liu, Nissim \& Thomas 2001:135 [19]. Fernandez 2001:6 [12] found that analysts have a preference for certain multiples in certain sectors, which supports the notion that different multiples are suited to different sectors.

In the Indian context, Zahir and Khanna 1982 [20] observed dividend per share as a significant determinant of share price. Kumar and Hundal 1986 [21] looked at the influence of various factors such as dividend per share, EPS, net sales per share, book value per share, net worth, retention ratio, leverage ratio and growth in total assets on market price of shares in a regression model. The analysis highlighted dividend per share and leverage as important factors. Sehgal and Pandey 2007 [22] observed the behavior of multiples, their means and standard deviation for the period 1990 to 2007. Their findings were that the PE multiples do not show greater influence; rather PBV and PS showed greater relationship with these fundamentals. Their inference was that PBV value and PS were more objective multiples-P/E could be influenced by arbitrary factors and market sentiments. Bhargava 2014 [23] examined factors influencing price multiples in India and identified market beta, dividend payout and growth estimates of the following year as key factors influencing stock valuations.

To the best of our knowledge, no study has explicitly examined the prediction accuracy of different multiples by using regression technique for specific sectors of Indian listed companies.

\section{Research Design and Methodology}

\subsection{Research Design}

The companies for the study have been taken from the BSE 500 (Bombay Stock Exchange) companies. We have selected the following three industries for performing our analysis:

- Automobile Industry: In this sector, data has been collected for passenger cars, commercial vehicles, two wheelers-scooters and bikes and auto ancillary companies.

- Banking Industry: The banking sector includes both private and public sector banks.

- Steel Industry: The steel industry includes large scale, medium and small scale companies.

The multiples which are used for the above mentioned sectors are:

- Price to Book Value Ratio.

- Price to Sales Ratio.

- Price to Earnings Ratio.

- Enterprise Value to EBITDA Ratio.

The rationale for choosing these three sectors for the purpose of this research study is that prior works and theoretical framework states that broadly, based on certain characteristics, a specific multiple defines the valuations of that sector. Steel sector is highly capital intensive with huge capex, depreciations and is also 
highly leveraged, thus, operating profits (EBIDTA) would define the sector valuations best. Book value per share is a good measure to value bank stocks. The alternative of comparing a stock's price to earnings, or price-to-earnings $(\mathrm{P} / \mathrm{E}) \mathrm{ra}$ tio, may produce unreliable valuation results, as bank earnings can swing in large variations from one quarter to the next due to unpredictable banking operations. In using book value per share, the valuation is referenced to equity that has less ongoing volatility in terms of percentage changes because equity has a much larger base, providing a more stable valuation measurement. As banks grow larger and expand into nontraditional banking activities, especially trading, their risk profiles become multidimensional and more difficult to construct, increasing business and investment uncertainties. This is presumably the main reason why bank stocks tend to be conservatively valued by investors who would be concerned about a bank's hidden risk exposures. The dataset for auto sector, in our study includes companies from a wide spectrum with different financial leverages, operating margins and not all companies in the sector are equally capital intensive, or growing at the same pace, therefore rather than earnings, EBIDTA or book values, their sales would define their valuations.

Based on this rationale these three sectors are identified to test if the valuation tools that theoretically define these sectors can be tested for their prediction accuracy.

A basic criterion for short listing the companies was availability of the required data for all the three years namely, FY 14 to FY 16. A total of 639 firm observations were there at the outset. The companies were identified on the basis of three criteria: 1) all multiples are positive, that is, multiples with negative values were discarded; 2) the companies have at least three years of positive company year multiples; and 3) each sector has at least four observations that meet criteria 1) and 2) above. Nel et al. 2013 [24], the first condition eliminates unrealistic multiples that cannot be used. The second condition ensures that selected companies have a reasonable history as a going concern, and the third condition ensures that the number of companies within each sector is not unnecessarily small, preventing the situation where there are too few observations. After filtering the original set for the above mentioned conditions, the total number of firm observations for the final analysis were 470 .

\subsection{Data Source}

The research study is based on secondary sources. The data is collected over three years 2013-14 to 2015-16. While the data being for 3 years can be a limitation of the present study, we believe that relative valuations are typically not used for long-term forecasting of stock prices, and thus taking historical data for longer span may not reflect on the fair value and impact our findings. Thus, the scope of present research is confined to three years.

Yahoo Finance and Capitaline are the database used for data collection on various fundamental drivers. The stock prices are taken from the BSE website. 
To minimize the estimation errors in our analysis, we thus chose matching companies on the basis of industry.

The data is collected on the following parameters:

- Market Price.

- Price to Sales Ratio.

- Price to Book value Ratio.

- Price to Earnings Ratio.

- Net Sales.

- Depreciation.

- Operating Profit (EBIT).

- EBITDA.

- Cash Flow.

- Enterprise value.

- Total Debt.

- Cash and Bank Balance.

- Total Shareholders Fund.

- Market Capitalization.

- Dividend Payout (\%).

- Profit After Tax.

- Size: It is a surrogate for risk.

\subsection{Methodology for Relative Valuations}

\section{- Regression Approach based on value drivers}

In contrast to the comparable firm' approach, the information in the entire cross-section of firms can be used to predict valuation multiples. The simplest way of summarizing this information is using multiple regression, with the multiple as the dependent variable, and proxies for risk, growth and payout forming the independent variables.

We have followed Damodaran 2007 [1] in deriving the key drivers for each multiple and using the same for predicted multiples. The Gordon Dividend Discount Model can be restated directly in terms of accounting information, without the need to assume a fixed relation between accounting data and future dividends and without restricting dividend policy. We replace dividends with earnings and book value to restate the expected price of a company's stock as a function of the market's expectations of future earnings and without severing the valuation link between price and future dividends.

Although a non-linear regression method can also be considered to derive the weights, we consider only the linear regression because of the following reasons: in theory, the equity value can be expressed by a linear combination of current earnings, book value of equity and the other information about future earnings under the assumption of linear information dynamics Ohlson; 1995 [25].

Depending on the industry we are looking to identify stock valuations, certain multiples are considered more appropriate than the others. Table 1 rationalizes the multiples broadly used for specific industries. 
Table 1. Multiples suited to specific sectors.

\begin{tabular}{|c|c|c|}
\hline Sector & Multiple Used & Rationale \\
\hline Cyclical Manufacturing & PE, Relative PE & $\begin{array}{l}\text { Often with normalized } \\
\text { earnings }\end{array}$ \\
\hline Growth firms & PEG ratio & $\begin{array}{l}\text { Big differences in growth } \\
\text { rates }\end{array}$ \\
\hline Young growth firms w/losses & Revenue Multiples & What choice do you have? \\
\hline Infrastructure & EV/EBITDA & Early losses, big DA \\
\hline REIT & $\begin{array}{c}\mathrm{P} / \mathrm{CFE} \\
(\text { where } \mathrm{CFE}=\text { Net income }+ \text { Depreciation })\end{array}$ & $\begin{array}{l}\text { Big depreciation charges } \\
\text { on real estate }\end{array}$ \\
\hline Financial Services & Price/Book equity & Marked to market? \\
\hline Retailing & Revenue multiples & $\begin{array}{l}\text { Margins equalize sooner or } \\
\text { later }\end{array}$ \\
\hline
\end{tabular}

Source: Damodaran.

\subsection{Deriving the Relationship between Multiples for Valuations} and Value Drivers

\section{1) Price Earnings Multiple}

\section{Fundamental parameter: Dividend payout ratio:}

Taking a simple Gordon dividend discount model $\mathrm{P}_{0}=\frac{\text { DPS }_{1}}{r-g_{n}}$

Dividing both sides by the earnings per share,

$$
\frac{\mathrm{P}_{0}}{\mathrm{EPS}_{0}}=\mathrm{PE}=\frac{\text { Payout Ratio*}\left(1+g_{n}\right)}{r-g_{n}}
$$

where $g$ is growth rate and $r$ is cost of equity.

2) Price to Sales (Revenue) Multiple

\section{Fundamental parameter: Net Profit Margin}

The price/sales ratio of a stable growth firm can be estimated from the DDM valuation model:

$$
\mathrm{P}_{0}=\frac{\mathrm{DPS}_{1}}{r-g_{n}}
$$

Dividing both sides by the sales per share:

$$
\frac{\mathrm{P}_{0}}{\text { Sales }_{0}}=\mathrm{PS}=\frac{\text { Profit Margin } * \text { Payout Ratio } *\left(1+g_{n}\right)}{r-g_{n}}
$$

\section{3) Price to Book Value Multiple}

\section{Fundamental Driver: ROE}

Going back to a simple dividend discount model, $\mathrm{P}_{0}=\frac{\mathrm{DPS}_{1}}{r-g_{n}}$

Defining the return on equity $(\mathrm{ROE})=\mathrm{EPS}_{0} / \mathrm{Book}$ Value of Equity, the value of equity can be written as:

$$
\frac{\mathrm{P}_{0}}{\mathrm{BV}_{0}}=\mathrm{PBV}=\frac{\mathrm{ROE} * \text { Payout Ratio } *\left(1+g_{n}\right)}{r-g_{n}}
$$




$$
\mathrm{P}_{0}=\frac{\mathrm{BV}_{0} * \mathrm{ROE}^{*} \text { Payout Ratio } *\left(1+g_{n}\right)}{r-g_{n}}
$$

4) Enterprise value to EBIDTA (earnings before interest, depreciation, tax and amortization)

Fundamental Drivers: Cost of capital, expected growth rate, tax rate, reinvestment rate (ROC)

Firm value can be written as:

$$
\mathrm{V}_{0}=\frac{\mathrm{FCFF}_{1}}{\text { WACC }-g}
$$

Now the value of the firm can be rewritten as

$$
\mathrm{EV}=\frac{\operatorname{EBITDA}(1-t)+\operatorname{Depr}(t)-\mathrm{Cex}-\Delta \text { Working Capital }}{\text { WACC }-g}
$$

Dividing both sides of the equation by EBITDA

$$
\begin{aligned}
\frac{\mathrm{EV}}{\text { EBITDA }}= & \frac{(1-t)}{\text { WACC }-g}+\frac{\text { Depr }(t) / \text { EBITDA }}{\text { WACC }-g}-\frac{\text { CEx } / \text { EBITDA }}{\text { WACC }-g} \\
& -\frac{\Delta \text { Working Capital } / \text { EBITDA }}{\text { WACC }-g}
\end{aligned}
$$

\section{Empirical Findings}

\subsection{Descriptive Statistics}

Table 2 presents the descriptive statistics of the ratios of value drivers to stock prices. The chosen five representatives of value drivers are:

\begin{tabular}{|c|c|c|c|c|c|c|}
\hline \multicolumn{7}{|c|}{ Statistics } \\
\hline & & EPS & CFPERSHARE & BVPERSHARE & SALESPERSHARE & EBIDTA/SHARE \\
\hline \multirow{2}{*}{$\mathbf{N}$} & Valid & 470 & 470 & 470 & 470 & 470 \\
\hline & Missing & 0 & 0 & 0 & 0 & 0 \\
\hline \multicolumn{2}{|c|}{ Mean } & 23.8837 & 38.9125 & 234.4478 & 539.4616 & 132.3908 \\
\hline \multicolumn{2}{|c|}{ Median } & 10.3800 & 17.3100 & 127.7200 & 262.6050 & 57.2550 \\
\hline \multicolumn{2}{|c|}{$\begin{array}{c}\text { Std. } \\
\text { Deviation }\end{array}$} & 34.41332 & 55.92649 & 353.49184 & 771.40158 & 237.30739 \\
\hline \multicolumn{2}{|c|}{ Minimum } & 0.01 & 0.01 & 0.45 & 0.55 & 0.05 \\
\hline \multicolumn{2}{|c|}{ Maximum } & 208.40 & 384.00 & 3251.40 & 7310.47 & 1901.76 \\
\hline \multirow{3}{*}{ Percentiles } & 25 & 2.7000 & 6.7575 & 45.4700 & 111.4625 & 18.4575 \\
\hline & 50 & 10.3800 & 17.3100 & 127.7200 & 262.6050 & 57.2550 \\
\hline & 75 & 31.8350 & 48.0825 & 268.6000 & 653.8250 & 150.2900 \\
\hline
\end{tabular}

- Earnings per share.

- Cash flow per share.

- Book value per share.

Table 2. Descriptive Statistics value drivers. 
- Sales or Revenue per share.

- EBIDTA per share.

It can be seen from Table 2, Table 3 that there is significant difference between the maximum and minimum values of the variables chosen. To eliminate the effect of outliers, we often choose median values instead of the mean.

\subsection{Regression Results}

\section{- Regressing market price on value drivers}

It can be seen from the Table 4 and Table 5 that when the market price is regressed against cash flow per share, book value per share, earnings per share, sales per share and EBIDTA per share there is a very strong relation between the dependent and independent variables as depicted in the $\mathrm{R}$ square which is $59 \%$. It can also be seen that there is high multicollinearity between earnings and cash flow as can be seen in their Variance Inflation factor. Earnings and book value are statistically significant, and emerge as significant predictors of market price for the entire dataset of 470 firm-observations together. We now proceed to analyze the sector wise results.

\subsubsection{Findings on the Auto Sector}

It can be seen from Table 6 that when regression is run on the auto sector firms, the best explaining multiples are EV/EBIDTA and Price/Sales as can be seen by their $\mathrm{R}$ square as $74 \%$ and $61 \%$ respectively. It is also observed that for EBIDTA multiple, expected growth rate, beta (explains the market risk), ROE, ROC and dividend payout are all statistically significant. We have run regression by checking for multicollinearity through VIF. It can also be seen that for P/S, net profit margins are statistically significant along with growth rates. We rationalize that these two multiples are significant for this sector in that the companies included in auto sector comprise from various segments and thus, it is difficult that the earnings or cash flow pattern will be consistent for such a vast spectrum of companies. Moreover being capital intensive, EBIDTA margins and also top

Table 3. Descriptive Statistics for multiples.

\begin{tabular}{cccccc}
\hline & & PSALES & PBV & PEARNINGS & EVEBIDTA \\
\hline & Valid & 470 & 470 & 470 & 470 \\
Missing & 0 & 0 & 0 & 0 \\
Mean & & 1.16 & 1.85 & 60.37 & 7.67 \\
Median & 0.46 & 1.08 & 13.38 & 5.41 \\
Std. Deviation & 2.122 & 2.285 & 441.224 & 12.136 \\
Minimum & 0 & 0 & 1 & 244 \\
Maximum & 22 & 22 & 9168 & 3.34 \\
& 25 & 0.23 & 0.52 & 7.64 & 5.41 \\
Percentiles & 50 & 0.46 & 1.08 & 13.38 & 11.11 \\
\hline
\end{tabular}


Table 4. Model summary.

\begin{tabular}{ccccc}
\hline Model & R & R Square & Adjusted R Square & $\begin{array}{c}\text { Std. Error of the } \\
\text { Estimate }\end{array}$ \\
\hline 1 & $0.768^{\mathrm{a}}$ & 0.590 & 0.586 & 454.00853 \\
\hline $\begin{array}{l}\text { a. Predictors: (Constant), EBIDTA/SHARE, SALESPERSHARE, EPS, BVPERSHARE, CFPERSHARE. b. } \\
\text { Dependent Variable: MARKETPRICE. }\end{array}$
\end{tabular}

Table 5. Regression output for variables impacting stock prices.

\begin{tabular}{|c|c|c|c|c|c|c|c|c|}
\hline & \multirow{2}{*}{ Model } & \multicolumn{2}{|c|}{$\begin{array}{c}\text { Unstandardized } \\
\text { Coefficients }\end{array}$} & \multirow{2}{*}{$\begin{array}{c}\text { Standardized } \\
\text { Coefficients } \\
\text { Beta }\end{array}$} & \multirow{2}{*}{$\mathrm{t}$} & \multirow{2}{*}{ Sig. } & \multicolumn{2}{|c|}{$\begin{array}{c}\text { Collinearity } \\
\text { Statistics }\end{array}$} \\
\hline & & B & Std. Error & & & & Tolerance & VIF \\
\hline \multirow{6}{*}{1} & (Constant) & 42.425 & 26.528 & & 1.599 & 0.110 & & \\
\hline & EPS & 17.749 & 1.832 & 0.866 & 9.687 & 0.000 & 0.111 & 9.046 \\
\hline & CFPERSHARE & 2.209 & 1.351 & 0.175 & 1.634 & 0.103 & 0.077 & 12.997 \\
\hline & BVPERSHARE & -0.210 & 0.109 & -0.105 & -1.935 & 0.054 & 0.297 & 3.362 \\
\hline & SALESPERSHARE & -0.064 & 0.052 & -0.070 & -1.235 & 0.218 & 0.272 & 3.681 \\
\hline & EBIDTA/SHARE & -0.800 & 0.128 & -0.269 & -6.233 & 0.000 & 0.473 & 2.113 \\
\hline
\end{tabular}

a. Dependent Variable: MARKETPRICE.

Table 6. Empirical results on the four multiples for auto sector.

\begin{tabular}{ccccc}
\hline & Price/Sales & Price/Book Value & Price/Earnings & EV/EBIDTA \\
\hline R & 60.9 & 50.9 & 14.4 & 74.2 \\
R square & 37.1 & 25.9 & 2.1 & 55.1 \\
Net Profit Margin & 24.118 & & & \\
& $(0.00)$ & & & \\
Growth rate & -21.853 & -29.426 & -1377.675 & -16.225 \\
& $(0.00)$ & $(0.00)$ & $(.036)$ & $(0.002)$ \\
Beta & -0.709 & & & -1.041 \\
& $(0.058)$ & & & $(0.00)$ \\
ROE & 0.066 & 0.325 & & 0.169 \\
& $(0.089)$ & $(0.00)$ & & $(0.00)$ \\
AGE & 0.0088 & & & \\
ROC & & & & $(0.00)$ \\
D/P & & & & -0.013 \\
& & & & $(0.016)$ \\
\hline
\end{tabular}

line in sales will explain the valuations best.

\subsubsection{Findings on the Banking Sector}

It can be observed from Table 7 that the multiple that best explains the banking sector is EV/EBIDTA followed by $\mathrm{P} / \mathrm{BV}$ and then $\mathrm{P} / \mathrm{Sales}$. The fundamental drivers for this sector include age of the company, beta (which explains market risk and is an indicator of the cost of equity), and ROC which explain EV/EBIDTA as significant predictors. The coefficient for age has a positive sign 
Table 7. Empirical results on the four multiples for banking sector.

\begin{tabular}{|c|c|c|c|c|}
\hline & Price/Sales & Price/Book Value & Price/Earnings & EV/EBIDTA \\
\hline $\mathrm{R}$ & 74.7 & 77.0 & 55.4 & 90.0 \\
\hline $\mathrm{R}$ square & 64.7 & 59.3 & 30.7 & 74.0 \\
\hline Net Profit Margin & $\begin{array}{l}32.418 \\
(0.023)\end{array}$ & & & \\
\hline Growth rate & & $\begin{array}{l}39.363 \\
(0.008)\end{array}$ & & $\begin{array}{c}-10.45381 \\
(0.003)\end{array}$ \\
\hline Beta & $\begin{array}{c}-0.672 \\
(0.00)\end{array}$ & $\begin{array}{l}-0.814 \\
(0.001)\end{array}$ & $\begin{array}{l}-6.258 \\
(0.009)\end{array}$ & $\begin{array}{l}1.142 \\
(0.00)\end{array}$ \\
\hline ROE & $\begin{array}{l}-0.531 \\
(0.008)\end{array}$ & & & \\
\hline AGE & $\begin{array}{c}0.193 \\
(0.042)\end{array}$ & $\begin{array}{l}0.405 \\
(0.00)\end{array}$ & $\begin{array}{l}3.218 \\
(0.00)\end{array}$ & \\
\hline ROC & & & & $\begin{array}{c}29.922 \\
(0.00)\end{array}$ \\
\hline Dividend Payout & & & $\begin{array}{l}-0.244 \\
(0.013)\end{array}$ & \\
\hline Depreciation & & & & $\begin{array}{l}0.286 \\
(0.00)\end{array}$ \\
\hline
\end{tabular}

showing that older companies with more established reputation and brand image will have higher multiples and thus higher valuations.

\subsubsection{Findings on the Steel Sector}

Table 8 shows that for steel sector, EV/EBIDTA shows maximum robustness followed by $\mathrm{P} / \mathrm{S}$ and $\mathrm{P} / \mathrm{BV}$. This is in line with our theoretical argument that for capital intensive sectors, EBIDTA is the appropriate measure of a firm's performance. It is also observed that the key value driver for each multiple is as derived in section III (Gordon model). The variables that are statistically significant and explain the sector best include beta, ROC, NPM and age of the company.

On running regression for all three sectors, we conclude that for PBV, ROE is the key driver; for EV/EBIDTA, ROC and for P/S, NPM is the key driver. This is consistent with the theoretical framework as advocated by Damodaran. It is also observed that the coefficients for ROE, ROC and NPM are positive implying that higher returns and higher profitability lead to higher multiples implying that the stock trades at higher multiples, with improved financial parameters. It can also be seen that beta has a negative sign for its coefficient implying that lower beta is associated with lower market risk and higher valuations, while higher beta indicates more volatility with market, and thus higher risk.

\subsection{Valuation Accuracy/Prediction Accuracy}

Prediction error is measured as the difference between the observed multiple and the predicted multiple. Absolute error will be

Observed multiple (actual)-predicted multiple

However, to enable cross-sectional analysis, this is scaled to control for the 
Table 8. Empirical results on the four multiples for steel sector.

\begin{tabular}{ccccc}
\hline & Price/Sales & Price/Book Value & Price/Earnings & EV/EBIDTA \\
\hline R & 57.9 & 54.4 & 20.8 & 73.0 \\
R square & 33.5 & 29.5 & 4.3 & 53.2 \\
Net Profit Margin & 15.130 & & & \\
& $(0.00)$ & & -444.4783 & \\
Growth rate & -7.00393 & & $(0.018)$ & \\
Beta & $(0.00)$ & & & -1.449 \\
ROE & & & & $(0.001)$ \\
AGE & 0.024 & $(0.103$ & & \\
ROC & $(0.012)$ & & & \\
& & & & \\
\end{tabular}

size effect. Thus, the percent error will be AM-PM/AM where AM is actual multiple, PM is the predicted multiple.

As a test statistics, we consider the following two statistics simultaneously, each of which measures the magnitude of the valuation errors by different ways:

1) Root Mean Square Error: It is used as a relative measure to compare forecasts or predicted values generated by a model with actual or observed values. According to this criterion, a smaller error in a model indicates the model is having better forecasting ability.

2) Theil Index: This measure is used more commonly in the field of economics, to identify inequalities. We have identified this measure to identify which multiple fits the sectors best. Theil's Inequality Coefficient is scale invariant. It always lies between 0 and 1 , where 0 indicates a perfect fit.

Through these two measures, we compare the multiples for each sector to identify least prediction error. The price multiple where pricing error, as per both measures, is least among the four multiples viz. $\mathrm{P} / \mathrm{E}, \mathrm{P} / \mathrm{BV}, \mathrm{P} / \mathrm{CF}$ and $\mathrm{P} / \mathrm{S}$, for most of the sectors is set as the most efficient one in forecasting prices.

It is seen from Table 9 that for auto sector, RMSE is least for EV/ EBIDATA followed by $\mathrm{P} / \mathrm{S}$ and then P/BV. For the Banking sector, the least RMSE is for $\mathrm{P} / \mathrm{BV}$ followed by EV/EBIDTA and then P/S. For Steel sector, EV/ EBIDTA has the least RMSE followed by P/S and then P/BV. These findings are in line with the theoretical framework used by academicians in identifying suitable multiples for different sectors. It can also be seen that for the purpose of this study, earnings are not relevant as multiple.

Table 10 on Theil index also substantiates our findings that EV/EBIDTA is superior followed by $\mathrm{P} / \mathrm{BV}$ and $\mathrm{P} / \mathrm{S}$.

We conclude from our findings of RMSE and Theil coefficient that least prediction errors are observed with EV/EBIDTA and maximum errors are observed in $\mathrm{P} / \mathrm{E}$. One reason for earnings not being significant is that historical earnings are considered while most valuations are based on forecasted earnings. Also, 
Table 9. Root Mean Square Error (RMSE).

\begin{tabular}{cccc}
\hline & AUTO SECTOR & BANKING SECTOR & STEEL SECTOR \\
\hline P/SALES & 1.7471 & 0.97377 & 1.8604 \\
P/BV & 2.3551 & 0.8844 & 1.9699 \\
P/EPS & 623.85 & 8.3151 & 198.92 \\
EV/EBIDTA & 1.6691 & 0.94623 & 1.7647 \\
\hline
\end{tabular}

Table 10. Theil index.

\begin{tabular}{cccc}
\hline MULTIPLES & AUTO SECTOR & BANKING SECTOR & STEEL SECTOR \\
\hline P/SALES & 0.3579449 & 0.2499766 & 0.4557657 \\
P/BV & 0.416412 & 0.0 .2321762 & 0.5489218 \\
P/EPS & 0.7797534 & 0.2775785 & 0.6840038 \\
EV/EBIDTA & 0.1825537 & 0.03162878 & 0.4036703 \\
\hline
\end{tabular}

earnings are more subject to creative accounting practices and may not always reflect the true value of a firm.

\section{Conclusions}

This study is conducted on an emerging market economy for Indian listed firms. Emerging markets differ from developed markets in terms of their accounting systems, liquidity, taxation laws among others. Thus the valuation techniques developed and researched for developed economies may not hold true in the Indian context. With increasing investments by institutional investors in the economy, it is imperative that valuations should reflect the true value of a company. This paper attempts to analyze prediction accuracy of 4 multiples across 3 sectors from 470 firm-observations.

Our findings show that revenue and EBIDTA margins are valuable indicators of valuations and that book value is more important than earnings. This may possibly be because the study relies on historical earnings. Prior research works on comparable approach have also established superiority of book value over earnings: Fama and French 1992 [26]. Even within historical earnings, the definition of earnings may give different results when it is before exceptional items, or it is basic or diluted. A primary reason for using multiples in equity valuation is that unlike dividend discount models and discounted cash flow techniques, these require simpler calculations and fewer assumptions with respect to profitability, growth rate, and discount rates among others. Thus, the probability of bias is somewhat reduced. Moreover, the stock price so determined is a function of an accounting variable that reflects the fundamentals of the company and also a multiple which is based on comparable firms, thus providing true estimates of the stock. However, the set of comparable firms chosen and the parameters chosen are likely to impact our predicted price. Thus it is crucial that selection of 
multiples, value drivers and set of comparable firms be identified with utmost prudence.

Improved valuation practices are likely to give different perspectives to investors in their decision to invest in an emerging market economy. The techniques used and parameters discovered can be deployed by analysts to add a perspective to their stock analysis. They may estimate various multiples with the regression models and compare the resultant price with the current price and bring out any potential upside/downside. Our research is relevant to practitioners, such as investment bankers and analysts, who use multiples to value companies, as well as to academic researchers. The results presented here may help such researchers choose multiples that minimize the potential bias embedded in the value measures.

\section{Limitations of the Study}

The research study has considered value drivers and multiples over three years only. The value drivers are based on historical accounting numbers rather than forecasted numbers, thus prediction accuracy may be better using forecasts (as has been done in previous works). Regression results are based on constant coefficients across all observations unlike benchmark method which provides accuracy in valuations for all observations. The benchmark valuation method can also be used for valuation of privately, and closely held firms. We have only used four multiples; if the number of multiples is increased, the result may vary. The sample size may not be completely representative and the findings may differ if we analyze for a larger dataset of companies.

\section{Scope of Future Research}

The limitations stated above can be overcome by ensuing further research in that direction. The research can be extended to incorporate data over 10 year horizon to evaluate the prediction accuracy of multiples. This study uses only information available in academic databases. Institutional investors and analysts often have access to more detailed data and can therefore calculate more precise fundamentals. For example, instead of attempting to estimate diluted book value per share using EPS data, analysts can incorporate information on options and convertible securities. With more precise estimates, some of the inferences of this study may change.

\section{Funding}

The infrastructure support provided by Fore School of Management, New Delhi in supporting this research in greatly appreciated.

\section{References}

[1] Damodaran, A. (2007) Valuation Approaches and Metrics: A Survey of the Theory and Evidence. Now Publishers, Hanover. 
[2] PricewaterhouseCoopers (2008) Valuation Methodology Survey. 1-62. http://www.pwc.com

[3] Lie, E. and Lie, H.J. (2002) Multiples Used to Estimate Corporate Value. Financial Analysts Journal, 58, 44-54. https://doi.org/10.2469/faj.v58.n2.2522

[4] Alford, A.W. (1992) The Effect of the Set of Comparable Firms on the Accuracy of Price Earnings Valuations Method. Journal of Accounting Research, 30, 94-108. https://doi.org/10.2307/2491093

[5] Bernard, V.L. (1994) Accounting-Based Valuation Methods, Determinants of Market to Book Ratios, and Implications for Financial Statements Analysis. Working Paper, University of Michigan, Michigan.

[6] Chan, L.K.C. and Chen, N.F. (1991) Structural and Return Characteristics of Small and Large Firms. Journal of Finance, 46, 1457-1484. https://doi.org/10.1111/j.1540-6261.1991.tb04626.x

[7] Kisor Jr., M. and Whitbeck, V.S. (1963) A New Tool in Investment Decision-Making. Financial Analysts Journal, 19, 55-62. https://doi.org/10.2469/faj.v19.n3.55

[8] Cragg, J.G. and Malkiel, B.G. (1968) The Consensus and Accuracy of Predictions of the Growth of Corporate Earnings. Journal of Finance, 23, 67-84.

https://doi.org/10.1111/j.1540-6261.1968.tb02998.x

[9] Zarowin, P. (1990) What Determines Earnings-Price Ratios: Revisited. Journal of Accounting, Auditing, and Finance, 5, 439-457.

[10] Agnes Cheng, C.A. and McNamara, R. (2000) The Valuation Accuracy of the Price-Earnings and Price-Book Benchmark Valuation Methods. Review of Quantitative Finance and Accounting, 15, 349-370.

[11] Kaplan, S.N. and Ruback, R. (1995) The Valuation of Cash Flow Forecasts: An Empirical Analysis. Journal of Finance, 50, 1059-1093. https://doi.org/10.1111/j.1540-6261.1995.tb04050.x

[12] Kim, M. and Ritter, J.R. (1999) Valuing IPOs. Journal of Financial Economics, 53, 409-437. https://doi.org/10.1016/S0304-405X(99)00027-6

[13] Hotchkiss, E.S. and Mooradian, R.M. (1998) Acquisitions as a Means of Restructuring Firms in Chapter 11. Journal of Financial Intermediation, 7, 240-262.

[14] Fernandez, P. (2001) Valuation Using Multiples: How Do Analysts Reach Their Conclusions? Working Paper, IESE Business School, Madrid, 1-13.

[15] Yoo, Y.K. (2006) The Valuation Accuracy of Equity Valuation Using a Combination of Multiples. Review of Accounting and Finance, 5, 108-123. https://doi.org/10.1108/14757700610668958

[16] Nel, W.S. (2009) The Use of Multiples in the South African Equity Market: Is the Popularity of the Price Earnings Ratio Justifiable from a Sector Perspective? Meditari Accountancy Research, 17, 101-115. https://doi.org/10.1108/10222529200900014

[17] Nel, W.S. (2010) A South African Perspective on the Multiples of Choice in the Valuation of Ordinary Shareholders' Equity: From Theory to Practice. African Journal of Business Management, 4, 930-941.

[18] Nissim, D. (2013) Relative Valuation of U.S. Insurance Companies. Review of Accounting Studies, 18, 324-359. https://doi.org/10.1007/s11142-012-9213-8

[19] Liu, J., Nissim, D. and Thomas, J. (2002) Equity Valuation Using Multiples. Journal of Accounting Research, 40, 135-172. https://doi.org/10.1111/1475-679X.00042

[20] Zahir, M.A. and Khanna, Y. (1982) Determinants of Stock Prices in India. The Chartered Accountant, 30, 521-523. 
[21] Kumar and Hundal (1986) Stock Market Integration Examining Linkages between India and Selected Asian Markets. Foreign Trade Review, 45, 3-18.

[22] Sehgal, S. and Pandey, A. (2007) The Behavior of Price Multiples in India (1990-2007). Asian Academy of Management Journal of Accounting and Finance, 5, 31-65.

[23] Bhargava, M. (2014) Factors Influencing Pricing Multiples in India. The IUP Journal of Applied Finance, 20, 23-33.

[24] Nel, W.S., Bruwer, B.W. and Roux, N.J. (2013) Equity- and Entity-Based Multiples in Emerging Markets: Evidence from JSE Securities Exchange. Journal of Applied Business Research, 29, 829-852. https://doi.org/10.19030/jabr.v29i3.7784

[25] Ohlson, J. (1995) Earning, Book Values, and Dividends in Equity Valuation. Contemporary Accounting Research, 11, 661-687. https://doi.org/10.1111/j.1911-3846.1995.tb00461.x

[26] Fama, E.F. and French, K. (1992) The Cross Section of Expected Stock Returns. The Journal of Finance, 47, 427-465. https://doi.org/10.1111/j.1540-6261.1992.tb04398.x 